\title{
Evaluation of the Physical Characteristics and Nutritional Value of Five Varieties of Dates (Phoenix dactylifera L.) in Two Years of Storage
}

\author{
Mehdi Orojloo $^{1 *}$ and Milad Orojloo \\ ${ }^{I}$ Master of Food Technology, University of Gorgan, morojlou@gmail.com \\ ${ }^{2}$ Master of Horticultural Sciences, Isfahan University of Technology, m.orojlou@ag.iut.ac.ir
}

\begin{abstract}
Article history:
Received date: 28 September, 2019

Review date: 7 October 2019

Accepted date:25 November 2019
\end{abstract}

\section{Keywords:}

physical characteristic, nutritional value, Phoenix dactylifera $L$.,

colorimetry, reducing sugar.

\begin{abstract}
Dates have a high nutritional value. Since the major part of harvesting, processing, packing and storing operation of this nutrient is done traditionally; so, in order to optimize processing equipment and determine the best storage conditions, the physical characteristics and changes in nutritional value of five varieties of dates, Piarom, Zahedi, Kaluteh, Kharak Berhi, and Mazafati were examined during two years of storage in a completely randomized statistical design and in a factorial manner. Statistical survey of results showed that the physical and nutritional characteristics of different varieties of dates had significant difference with each other $(P<0.05)$; depending on variety, the moisture content of samples was obtained respectively from 19.29 to 72.07 percent. The results indicated that length, width, thickness, geometric mean diameter, surface area, and sphericity coefficient for the varieties of examined dates were respectively from 27.98 to $41.07 \mathrm{~mm}, 19.55$ to $24.95 \mathrm{~mm}, 16.94$ to $20.70 \mathrm{~mm}, 23.16$ to $25.95 \mathrm{~mm}, 1781.77$ to $2121.72 \mathrm{~mm} 2$, and also variable from 58.01 to 82.84 percent. The volume of fruit, the mass of fruit, the mass of seed, as well as the ratio of the mass of seed to the mass of fruit were obtained respectively from 6.45 to $10.79 \mathrm{~cm} 3,5.93$ to $12.71 \mathrm{~g}, 0.79$ to $0.96 \mathrm{~g}$ and 7.71 to $16.64 \%$. True density, bulk density and porosity content of samples were calculated from 913 to $1185 \mathrm{~kg} / \mathrm{m} 3,472$ to $601 \mathrm{~kg} / \mathrm{m} 3$ and 46.66 to $58.01 \%$. Static coefficient of friction of the varieties of dates was determined on surfaces made of wood, chipboard, plywood, rough cardboard, stone and glass from 0.38 to 0.87. Colorimetry indexes $L, a$ and $b$ were also measured respectively from 2.8 to 43.7, 3.2 to 24.9 and -9 to 43.6 for different varieties. The $\mathrm{pH}$ amount of different varieties of dates during storage in the warehouse in the months 0,12 and 24 was obtained respectively from 6.3 to 6.97, 5.91 to 6.41 and 5.78 to 6.31. The amount of acidity during storage of varieties of dates in the warehouse and in the months 0,12 and 24 was also determined respectively from 0.094 to $0.255,0.163$ to 0.282 and 0.214 to 0.297 . The amount of reducing sugars different varieties of dates during storage in the refrigerator and in the months 0,12 and 24 were determined respectively from 50.31 to $61.78,41.39$ to 57.97 and 36.10 to $55.65 \%$.
\end{abstract}

Please cite this article as: Orojloo, M., Orojloo,Mi. 2019. Evaluation of the Physical Characteristics and Nutritional Value of Five Varieties of Dates (Phoenix dactylifera L.) in Two Years of Storage. ALKHAS; The Journal of Environment, Agriculture and Biological Sciences, 1(1), 1-10

\section{Introduction:}

Date (Phoenix dactylifera L.) is the fruit of palm tree which can be various in terms of color, shape as well as size and can be soft, semi-dry or dry in terms of texture. This fruit has a lot of sugar. The amount and type of sugar are different among various varieties. The amount of vitamin $\mathrm{C}$ in fresh dates is relatively high, but it can be small with drying. Dates are used to prepare desserts, cakes and biscuits [1]. Processing industries produce a variety of products from dates, like date paste, date syrup, date sauce, date honey, date jam, date vinegar, etc. [2]. Now, almost 2,000 different varieties of dates are known, but only a few numbers of their key varieties have been evaluated due to the performance and quality of their fruit [3]. Dates are grown in 35 countries and on a surface area of 1.17 million hectares. The global production of dates in 2004 is estimated about 6.77 million tons [4]. FAO estimated the production amount of dates in 2005 around 7.6 million tons [5]. The fruit of date is one of the most important and oldest agricultural products in Iran. Some people 
especially in the southern part of Iran earn their living income from dates [6]. Iran in 2004, with $14 \%$ of global production was known as the world's second largest producer of dates [4]. Iran in 2006, with production of one million tons of date fruit and export of more than 143 thousand tons was one of the largest producers of dates in the world. There are about 400 different varieties of dates in Iran; however, the Mazafati variety is the most famous and delicious kind, it is usually considered as a soft or wet variety [7]. There are four distinct stages during the handling process of the fruit of dates. In the first stage which is called the Kimri, dates are green and have high moisture and acidity and a slight amount of sugar. In the second stage, which is called Kharak or Khalal, skin color of Mazafati dates becomes red and the amount of acidity as well as the size of dates is reduced while they have the increased sugar content. At the stage of Rutab, Mazafati dates get brown as well as softer, and they have a higher amount of sugar. In the final stage, which is called Tamr, dates are black and have low moisture amount as well as high sugar content with good storage characteristics [8]. The results have shown that the concentration of sugar and organic acid, depending on the type of dates and the stage of growth they are located, is different; then, reaches its maximum value at this stage where glucose and fructose are known as the major sugars and Malic acid is considered as the main organic acid. Decreases in sucrose correlated with increases in both, glucose and fructose concentrations, suggesting a sharp increase in invertase activities, which cause inversion of sucrose into glucose and fructose [9]. Considering the importance of sugar in dates, many studies have been done in this area; for example, optimizing the enzymatic extraction of sugars from the fruit of date of Kabkab variety has been taken into account [10].

Recently, interest in antioxidants due to their high capacity in removing free radicals associated with various diseases, has increased [11]. It has been shown that existing phytochemicals in fruits have a considerable antioxidant capacity that can be related to less outbreak of deteriorating diseases with the less rate of mortality resulted from them in humans [12]. The date is known as a foodstuff with antioxidant and antimutant (anti-mutagenic) properties [13]. Dates can be used as a good source of natural antioxidants [9]. It has been proved that extract of dates has antioxidant effects [14]. The ability of Iranian dates has also been proved as a pragmatic anti-oxidant ingredient [15]. However, a few reports are available about the functional characteristics of the fruit of date and especially about its changes during the fruit processing. The subject in recent years and when it was shown, diets with plenty of fruits and vegetables associated with lower risk of developing a number of diseases and serious health disorders, including coronary artery disease, some types of stroke, certain types of cancer, weakened immune systems, brain dysfunction and cataracts are of greater importance [16-17]. It has recently been determined that the fruit of date can be helpful in sugar and fat control of diabetic patients [18] and shown that date extract can act as a protective factor in nerves in the peripheral nerve diseases caused by diabetes in rats [19]. Some researchers have suggested that replacing some part of dietary carbohydrate with dates can be useful in controlling women's type II blood sugar [20]. Although some have also shown that date consumption compared to eating sugar cube would not have an advantage to type I diabetic patients [21]. Considering the role of deterrence that dates play in growing Streptococcus Mutans; so, they can be introduced as a preventive food of creating dental caries [22]. Date seed constitutes $10 \%$ of the total weight of dates, and it can be seen in the form of waste in date processing workshops [23]. Date seed contains $8.5-10.8 \%$ oil. The results show that date seed oil can be used in the preparation of cosmetic, pharmaceutical and food products [23-24]. This study showed that date seed extract would have an anti-bacterial activity against some isolated strains of Staphylococcus aureus [25]. Unfortunately, despite the high nutritional value and high volume production of dates, a major part of manufacturing, storing and processing is still done manually and traditionally. Knowledge of the physical characteristics of different varieties of dates to mechanize more these processes is necessary. Industrialization of production cycle, processing, packing and storing dates results in increased quality of the final product and retaining more its nutritional value. Despite the research conducted in the field of physical properties of dates [26-29], due to the large variety of dates, doing more research in this area is essential. With regard to the massive volume of manufacturing dates in Iran, it has always been a need to store some part of the product before presenting to the consumer market. In this regard, knowledge of changes made during the period of storage can be helpful in making better decisions in this field. Therefore, the present research in order to respond to these needs has dealt with examining the physical characteristics of five main varieties produced in Iran and the effect of storage on their nutritional characteristics during the two years of storage.

\section{Materials and method:}


In order to carry out the study in August 2013, samples of five common date varieties consumed a lot in Iran, including Piarom, Zahedi, Kaluteh, Berhi and Mazafati "Figure 1", were purchased from local markets located in main centers of production of these varieties and transferred to the laboratory for more examination after packing in polyethylene cover. The samples during storage were kept at 5 degrees Celsius. The varieties Piarom, Zahedi, Kaluteh, Berhi and Mazafati were prepared respectively from regions, Haji Abad, Bushehr, Jiroft, Abadan and Bam "Figure 2".

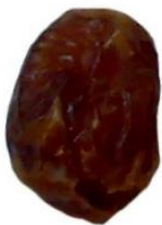

Zahedi

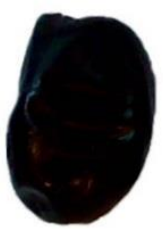

Mazafati

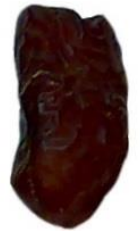

Piarom

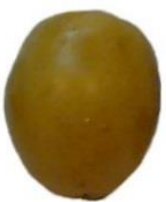

Kharak Berhi

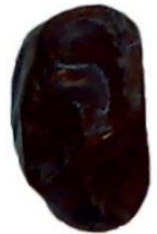

Kaluteh

Figure 1: studied varieties in this research

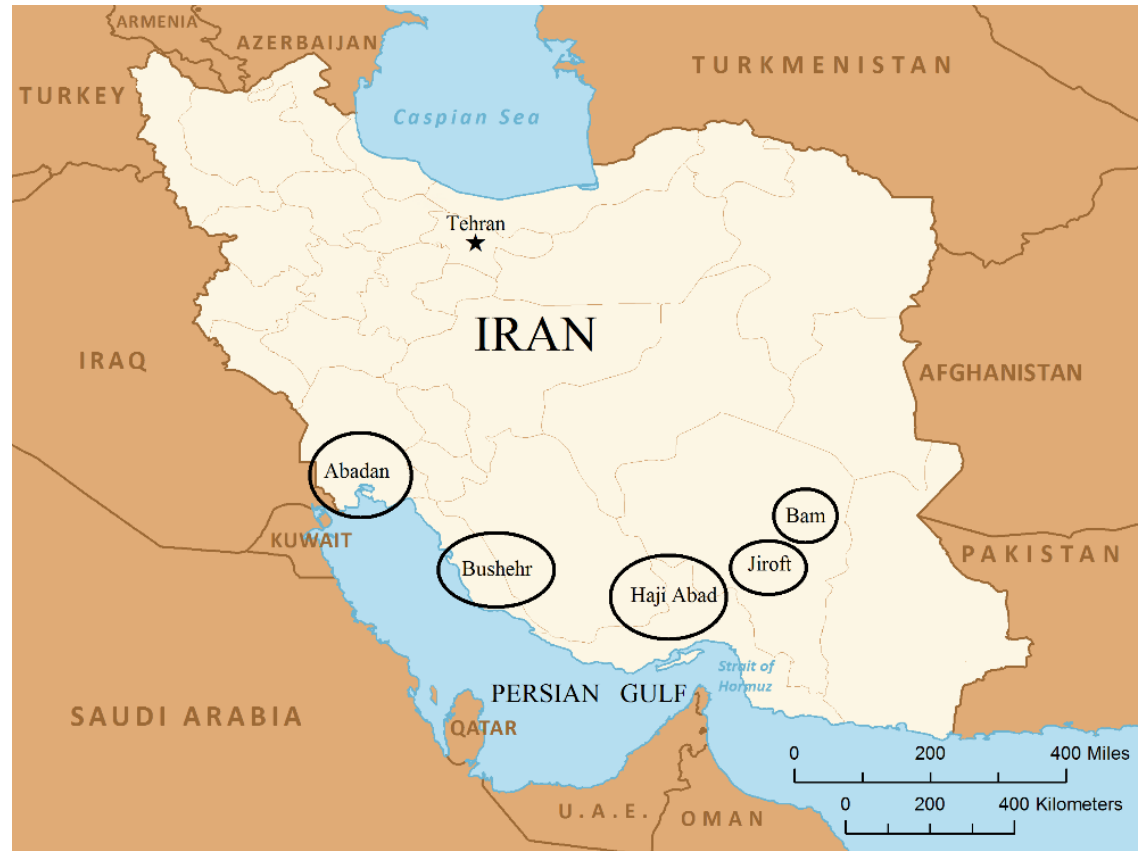

Figure 2: production regions of studied varieties in this research

After the removal of defective samples, the study was done on the nutritional and physical characteristics of the samples. The wet-basis moisture content of samples was determined using the inclusion of 10 grams of samples in an oven with a temperature of $103 \pm 3{ }^{\circ} \mathrm{C}$ until reaching constant weight and in accordance with the standard and using equation (1) [30].

$\mathrm{M}_{\mathrm{c}}=\left[\frac{\left(\mathrm{M}_{1}-\mathrm{M}_{2}\right)}{\mathrm{M}_{1}}\right] \times 100$

Where $M_{c}$ is considered as wet-basis moisture, $M_{1}$ as initial weight of samples, and $M_{2}$ as weight of samples after putting in an oven. In order to determine the average moisture content of the samples, the experiment was carried out in three replications.

In order to determine dimensions of dates, 50 pieces of date fruit of each variety were selected randomly, and three main dimensions perpendicular to them, including length $(\mathrm{L})$, width $(\mathrm{W})$ and thickness $(\mathrm{T})$ using a caliper (Tricle Brand, China) and with precision of $0.02 \mathrm{~mm}$ were measured "Figure 3". Geometric mean diameter $(\mathrm{Dg})$ in terms of $\mathrm{mm}$ and sphericity coefficient $(\Phi)$ in terms of percentage was calculated using equations (2) and (3) [31]. The surface area of dates was also calculated from equation (4) [32].

$\mathrm{D}_{\mathrm{g}}=(\mathrm{LWT})^{0.333}$

$\Phi=\left(\frac{\mathrm{D}_{\mathrm{g}}}{\mathrm{L}}\right) \times 100$ 

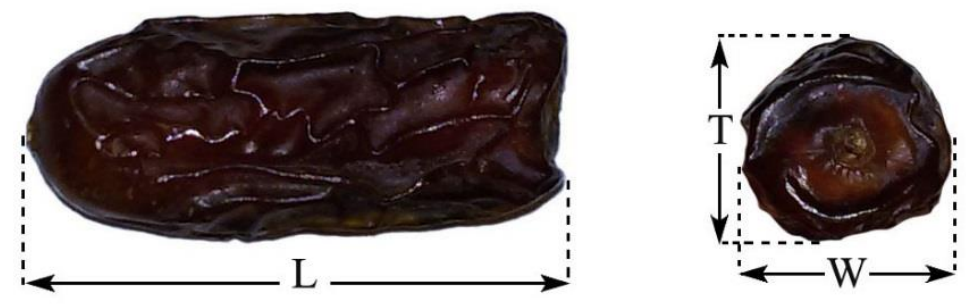

Figure 3: determining dimensions of dates

The mass of dates was measured using a digital scale (MH-200, CHINA) with precision of 0.01g. The mass of different varieties of date seed was also determined with the same method. In order to determine the ratio of the mass of date seed to the mass of total dates, first the mass of full seeds as well as the mass of seed of all of them were measured, and then equation (5) was used for this purpose where $\mathrm{m}$ is considered as the mass of date seed in terms of $\mathrm{g}, \mathrm{M}$ as the mass of full dates in terms of $\mathrm{g}$ and $\mathrm{R}$ as the ratio of seed to the mass of full fruit of dates in terms of percentage.

$\mathrm{R}=\frac{\mathrm{m}}{\mathrm{M}} \times 100$

The volume of fruits was also measured using water displacement method. The fruits were initially weighted in the air and then immersed inside water; they were dipped in water-containing glassware by a needle, and the mass of displaced water was recorded by each fruit. Finally, true density of dates $\left(\rho_{t}\right)$ was determined using equation (6) and in terms of $\mathrm{cm}^{3}$. In this relation, $\rho_{\mathrm{w}}$ is considered as the density of water in terms of $\mathrm{cm}^{3}, \mathrm{M}_{\mathrm{a}}$ and $\mathrm{M}_{\mathrm{w}}$ as the mass of dates in the air and water respectively. To determine the bulk density $\left(\rho_{\mathrm{b}}\right)$, first, a cylindrical container was filled with a characterized volume of fruits of dates, and then, according to equation (7), the amount of mass density was determined by dividing the mass of fruits by the volume of the container. In this relation, $\mathrm{m}_{\mathrm{b}}$ is considered as the mass of bulk in terms of $\mathrm{g}$ and $\mathrm{v}_{\mathrm{b}}$ as the volume of cylindrical container in terms of $\mathrm{cm}^{3}$. In the end, the results of densities were also determined and reported in terms of $\mathrm{kg} / \mathrm{m}^{3}$. Porosity percentage of the mass of fruits $(\varepsilon)$ was calculated from equation (8), as well [33].

$\rho_{\mathrm{t}}=\left[\frac{\mathrm{M}_{\mathrm{z}}}{\mathrm{M}_{\mathrm{z}}-\mathrm{M}_{\mathrm{W}}}\right] \times 100$

$\rho_{\mathrm{b}}=\frac{\mathrm{m}_{\mathrm{b}}}{\mathrm{v}_{\mathrm{b}}}$

$\varepsilon=\left[1-\left(\frac{\rho_{b}}{\rho_{t}}\right)\right] \times 100$

Static coefficient of friction $(\mu s)$ of types of dates was calculated for surfaces made of wood, chipboard, plywood, glass, stone and rough cardboard. For this purpose, a steep surface with adjustable tilt was applied. In this method, fruits were poured inside a vessel without head and bottom with dimensions $20 \times$ $10 \times 5 \mathrm{~cm}$ which was located on the desired surface. At first, the vessel was lifted up a little from the desired surface to prevent from any contact between the vessel and surface; then, it was proceeded to raise the steep surface and increase the slope of the surface. According to equation (9), tangent of an angle that the box containing fruits are on the brink of moving $(\alpha)$ is equal to the static coefficient of friction [33].

$\mu_{\mathrm{s}}=\tan \alpha$

A model that is now more conventional for food color measurement is a color space CIELab or the same Lab where $\mathrm{L}$ is the component of brightness or transparency which its value is variable from the range of 0-100; the number 0 represents black and 100 represents white. Parameter a is considered as the green to red component and parameter $b$ as the blue to yellow component of one color. The scope of these two components can be an unlimited color, but their scope is usually considered from -120 to +120 . When the sample color goes to red, the value of a will be positive, and when it tends to green, the value of a will be negative. Also, when the sample color goes to yellow, the value of $\mathrm{b}$ will be positive, and when it tends to blue, the value of $\mathrm{b}$ will be negative. In order to measure colorimetry indexes, a device (Alborz Color Scanner-MH94, Iran) was used [34-35].To measure $\mathrm{pH}$ of the samples, a $\mathrm{pH}$ meter device (AZ-8686, Taiwan) with precision of 0.01 units was applied. For this purpose, $5 \mathrm{~g}$ of date samples was put in a pastle 
and mortar and $100 \mathrm{ml}$ of distilled water were added to it; then, it was stirred by a mixer for 15 minutes at a speed of $150 \mathrm{rpm}$, and after smoothing down the solution obtained by filter paper (Filtrak, Germany), its $\mathrm{pH}$ was read at a temperature of 25 degrees Celsius. To measure acidity of the samples, $5 \mathrm{~g}$ of the date sample was put in a pastle and mortar, and $50 \mathrm{ml}$ of distilled water was added to it; then, it was stirred by a mixer for 15 minutes at a speed of $150 \mathrm{rpm}$, and the obtained solution was smoothed down. Then, it was titrated by a 0.1 Normal Sodium Hydroxide solution to reach $\mathrm{pH}=8.6$, and the acidity value was calculated by equation (10).

$\mathrm{Z}=\frac{\mathrm{V} \times \mathrm{N} \times \mathrm{Meq} \times 100}{\mathrm{~W}}$

In this relation, $\mathrm{V}$ is equal to the volume of consumer interest to $\mathrm{ml}, \mathrm{N}$ is equal to consumer interest normality, Meq is equal to Malic acid meq (0.067), and W is equal to mass of the sample in mg [36].

The amount of reducing sugars of the samples was determined using Lane and Eynon method in three replications [37].

All the samples were maintained during storage at a temperature of $5^{\circ} \mathrm{C}$. Measurement of all the physical characteristics of the samples was carried out at the beginning of the first month of maintenance, but measurement of the nutritional characteristics was conducted at three times (beginning of the first month, end of the twelfth month, and end of the twenty fourth month). All measurements were carried out in three replications. Since the variety of Berhi is consumed more at the Kharak stage, and during the maintenance period in storage due to the occurrence of processing, it becomes Rutab; therefore, in the case of this variety, merely its physical properties have been taken into account.

Analysis of data obtained from this research was conducted using a completely randomized statistical design and in a factorial manner by means of statistical software SPSS 20; and Comparison between means was done with Duncan's test at level $\mathrm{P}=0.05$.

\section{Results and discussion:}

As seen in "Table 1", the percentage of moisture in different varieties of dates has a significant difference, and its maximum with $72.07 \%$ is allocated to Kharak Berhi. In terms of dimensions, a significant difference can also be seen between the studied varieties. The most value of length, width, thickness and geometric mean diameter in terms of mm respectively with 41.07, 24.95, 20.70 and 25.95 can be allocated to the varieties, such as Piarom, Mazafati, Kharak Berhi and Mazafati. The least amount of length with $27.98 \mathrm{~mm}$ belongs to Kharak Berhi. The variety, Piarom with the width of $19.55 \mathrm{~mm}$ and the thickness of $16.94 \mathrm{~mm}$ has allocated the least amount to itself. In terms of surface area and sphericity percentage, a significant difference is also seen among the varieties. The most surface area with 2121.72 $\mathrm{mm}^{2}$ is allocated to the variety, Mazafati; and the least amount of it with $1685.31 \mathrm{~mm}^{2}$ to Kharak Berhi. The most and least sphericity with $82.84 \%$ and $55.01 \%$ is also allocated to the varieties, Kharak Berhi and Piarom respectively.

Table 1: geometric characteristics of five varieties of studied dates

\begin{tabular}{cccccccc}
\hline Variety & $\begin{array}{c}\text { Wet-basis } \\
\text { moisture } \\
\text { content }(\%)\end{array}$ & Length $(\mathrm{mm})$ & Width $(\mathrm{mm})$ & $\begin{array}{c}\text { Thickness } \\
(\mathrm{mm})\end{array}$ & $\begin{array}{c}\text { Geometric } \\
\text { mean diameter } \\
(\mathrm{mm})\end{array}$ & $\begin{array}{c}\left.\text { Surface area }(\mathrm{mm})^{2}\right) \\
(\%)\end{array}$ & $\begin{array}{c}\text { Sphericity } \\
(\%)\end{array}$ \\
\hline Piarom & $19.29 \pm 1.81^{\mathrm{c}}$ & $41.07 \pm 3.60^{\mathrm{a}}$ & $19.55 \pm 1.83^{\mathrm{d}}$ & $16.94 \pm 1.75^{\mathrm{d}}$ & $23.76 \pm 1.78^{\mathrm{d}}$ & $1781.77 \pm 266.01^{\mathrm{d}}$ & $58.01 \pm 3.45^{\mathrm{d}}$ \\
Zahedi & $20.57 \pm 1.36^{\mathrm{c}}$ & $33.14 \pm 2.66^{\mathrm{c}}$ & $22.67 \pm 1.68^{\mathrm{b}}$ & $19.77 \pm 1.52^{\mathrm{bc}}$ & $24.47 \pm 1.43^{\mathrm{c}}$ & $1886.76 \pm 221.73^{\mathrm{c}}$ & $74.03 \pm 3.07^{\mathrm{b}}$ \\
Kaluteh & $20.90 \pm 0.64^{\mathrm{c}}$ & $35.74 \pm 2.64^{\mathrm{b}}$ & $23.31 \pm 1.95^{\mathrm{b}}$ & $19.45 \pm 2.10^{\mathrm{c}}$ & $25.15 \pm 1.20^{\mathrm{b}}$ & $1991.11 \pm 188.99^{\mathrm{b}}$ & $70.62 \pm 4.53^{\mathrm{c}}$ \\
Kharak berhi & $72.07 \pm 0.38^{\mathrm{a}}$ & $27.98 \pm 1.25^{\mathrm{d}}$ & $21.66 \pm 0.91^{\mathrm{c}}$ & $20.70 \pm 0.74^{\mathrm{a}}$ & $23.16 \pm 0.73^{\mathrm{d}}$ & $1685.31 \pm 104.46^{\mathrm{e}}$ & $82.84 \pm 2.80^{\mathrm{a}}$ \\
Mazafati & $33.27 \pm 0.64^{\mathrm{b}}$ & $34.86 \pm 1.75^{\mathrm{b}}$ & $24.95 \pm 1.24^{\mathrm{a}}$ & $20.40 \pm 2.63^{\mathrm{ab}}$ & $25.95 \pm 1.54^{\mathrm{a}}$ & $2121.72 \pm 252.99^{\mathrm{a}}$ & $74.46 \pm 3.02^{\mathrm{b}}$ \\
\hline
\end{tabular}

In each column, averages with the same letters do not have a significant difference with each other at the level of $\mathrm{P}<0.05$.

By viewing "Table 2", it is also indicated that there are significant differences between different varieties of dates in terms of geometric characteristics. In terms of the volume of fruit, the varieties, Mazafati and Kharak Berhi respectively with 10.79 and $6.45 \mathrm{~cm}^{3}$ have the most and least values. These two varieties in 
terms of the mass of fruit and true density have also allocated respectively the most and least values to themselves. Although in terms of the mass of seed, the varieties of Mazafati, Kharak, Berhi and Piarom have allocated the most value to themselves, in terms of the percentage of the mass of the seed to the total mass of fruit, the variety of Mazafati with $7.71 \%$ has the least value. The most and least mass density respectively with 601 and $472 \mathrm{~kg} / \mathrm{m}^{3}$ belongs to the varieties of Mazafati and Kaluteh. The variety of Kaluteh with $58.01 \%$ and Kharak Berhi with $46.66 \%$ respectively has the most and least percentage of porosity.

Table 2: geometric characteristics of five varieties of studied dates

\begin{tabular}{cccccccc}
\hline Variety & Volume & Fruit mass & $\begin{array}{c}\text { Seed mass } \\
(\mathrm{g})\end{array}$ & $\begin{array}{c}\text { Seed mass to } \\
\text { fruit mass ratio } \\
(\%)\end{array}$ & $\begin{array}{c}\text { Fruit True } \\
\text { density } \\
\left(\mathrm{Kg} / \mathrm{m}^{3}\right)\end{array}$ & $\begin{array}{c}\text { Fruit bulk } \\
\text { density } \\
\left(\mathrm{Kg} / \mathrm{m}^{3}\right)\end{array}$ & $\begin{array}{c}\text { Porosity } \\
(\%)\end{array}$ \\
\hline Piarum & $7.02 \pm 1.41^{\mathrm{bc}}$ & $8.11 \pm 1.78^{\mathrm{b}}$ & $0.96 \pm 0.17^{\mathrm{a}}$ & $12.11 \pm 2.14^{\mathrm{b}}$ & $1170 \pm 87^{\mathrm{ab}}$ & $553 \pm 3.5^{\mathrm{b}}$ & $52.69 \pm 0.30^{\mathrm{b}}$ \\
Zahedi & $6.95 \pm 1.24^{\mathrm{bc}}$ & $7.41 \pm 1.19^{\mathrm{c}}$ & $0.79 \pm 0.13^{\mathrm{c}}$ & $10.78 \pm 1.62^{\mathrm{c}}$ & $1042^{2} \pm 79^{\mathrm{c}}$ & $506 \pm 16.4^{\mathrm{c}}$ & $51.45 \pm 1.57^{\mathrm{b}}$ \\
Kalute & $7.34 \pm 0.81^{\mathrm{b}}$ & $8.11 \pm 1.08^{\mathrm{b}}$ & $0.86 \pm 0.12^{\mathrm{b}}$ & $10.71 \pm 1.40^{\mathrm{c}}$ & $1123 \pm 126^{\mathrm{b}}$ & $472 \pm 12.6^{\mathrm{d}}$ & $58.01 \pm 1.12^{\mathrm{a}}$ \\
Kharak berhi & $6.45 \pm 0.81^{\mathrm{c}}$ & $5.93 \pm 0.64^{\mathrm{d}}$ & $0.97 \pm 0.13^{\mathrm{a}}$ & $16.64 \pm 2.92^{\mathrm{a}}$ & $913 \pm 36^{\mathrm{d}}$ & $487 \pm 2.6^{\mathrm{cd}}$ & $46.66 \pm 0.29^{\mathrm{d}}$ \\
Mazafati & $10.79 \pm 1.51^{\mathrm{a}}$ & $12.71 \pm 1.56^{\mathrm{a}}$ & $0.97 \pm 0.12^{\mathrm{a}}$ & $7.71 \pm 1.24^{\mathrm{d}}$ & $1185 \pm 55^{\mathrm{a}}$ & $601 \pm 18.5^{\mathrm{a}}$ & $49.29 \pm 1.56^{\mathrm{c}}$ \\
\hline
\end{tabular}

In each column, averages with the same letters do not have a significant difference with each other at the level of $\mathrm{P}<0.05$.

Different varieties of dates in terms of static coefficient of friction on various surfaces have also significant differences with each other "Table 3". On all three surfaces of wood, chipboard and plywood, the Mazafati and Kaluteh varieties have allocated the most coefficient of friction to themselves. On the stone surface, the most coefficient of friction belongs to the Kaluteh variety. On the rough cardboard and glass surface, the Mazafati, Kaluteh and Zahedi varieties have allocated the most value of static coefficient of friction to themselves.

Table 3: static coefficient of friction of different varieties on various surfaces

\begin{tabular}{|c|c|c|c|c|c|c|}
\hline \multirow{2}{*}{ Variety } & \multicolumn{6}{|c|}{ Static coefficient of friction } \\
\hline & Wood & Chipboard & Plywood & $\begin{array}{c}\text { Rough } \\
\text { cardboard }\end{array}$ & Stone & Glass \\
\hline Piarom & $0.50 \pm 0.01^{b}$ & $0.50 \pm 0.04^{b c}$ & $0.66 \pm 0.08^{b}$ & $0.47 \pm 0.02^{b}$ & $0.47 \pm 0.02^{\mathrm{c}}$ & $0.41 \pm 0.05^{b}$ \\
\hline Zahedi & $0.51 \pm 0.02^{b}$ & $0.61 \pm 0.08^{b}$ & $0.56 \pm 0.04^{c}$ & $0.79 \pm 0.09^{a}$ & $0.60 \pm 0.02^{b}$ & $0.55 \pm 0.02^{a}$ \\
\hline Kaluteh & $0.74 \pm 0.14^{\mathrm{a}}$ & $0.85 \pm 0.13^{\mathrm{a}}$ & $0.78 \pm 0.03^{a}$ & $0.87 \pm 0.06^{\mathrm{a}}$ & $0.72 \pm 0.06^{\mathrm{a}}$ & $0.53 \pm 0.05^{\mathrm{a}}$ \\
\hline Kharak berhi & $0.40 \pm 0.04^{b}$ & $0.41 \pm 0.07^{\mathrm{c}}$ & $0.43 \pm 0.02^{\mathrm{d}}$ & $0.39 \pm 0.02^{b}$ & $0.43 \pm 0.01^{\mathrm{c}}$ & $0.38 \pm 0.02^{b}$ \\
\hline Mazafati & $0.87 \pm 0.11^{a}$ & $0.84 \pm 0.05^{\mathrm{a}}$ & $0.78 \pm 0.03^{a}$ & $0.84 \pm 0.06^{\mathrm{a}}$ & $0.59 \pm 0.06^{b}$ & $0.54 \pm 0.02^{a}$ \\
\hline
\end{tabular}

In each column, averages with the same letters do not have a significant difference with each other at the level of $\mathrm{P}<0.05$.

"Table 4" indicates well the effect of a variety on color of types of dates. The high value of parameter L in Kharak Berhi indicates more brightness of its color than other varieties. While higher parameter of a in the Zahedi variety in comparison with other varieties indicates more tendency of color of this variety to the red side. Allocation of the most value of parameter $b$ to Kharak Berhi also indicates a tendency of color of this variety to the yellow side.

Table 4: color indexes of different varieties dates

\begin{tabular}{cccc}
\hline Variety & $\mathrm{L}$ & $\mathrm{a}$ & $\mathrm{B}$ \\
\hline Piarom & & & \\
\hline
\end{tabular}


The Journal of Environment, Agriculture and Biological Sciences, 1(1), 1-9

\begin{tabular}{|c|c|c|c|}
\hline Zahedi & $14.5 \pm 0.6^{b}$ & $24.9 \pm 1.3^{\mathrm{a}}$ & $20.5 \pm 1.2^{b}$ \\
\hline Kaluteh & $2.8 \pm 0.1^{\mathrm{d}}$ & $8.5 \pm 0.3^{c}$ & $4.5 \pm 0.4^{\mathrm{c}}$ \\
\hline Kharak berhi & $43.7 \pm 1.6^{\mathrm{a}}$ & $7.8 \pm 0.2^{c}$ & $43.6 \pm 2.3^{\mathrm{a}}$ \\
\hline Mazafati & $9.2 \pm 0.5^{\mathrm{c}}$ & $3.2 \pm 0.1^{\mathrm{c}}$ & $-9.0 \pm 2.2^{\mathrm{d}}$ \\
\hline
\end{tabular}

In each column, averages with the same letters do not have a significant difference with each other at the level of $\mathrm{P}<0.05$.

Both factors of variety and duration of maintenance in the store had a significant effect on the $\mathrm{pH}$ value of samples of dates " Table 5". Among fresh samples, the most and least $\mathrm{pH}$ value with 6.97 and 6.03 respectively belongs to the Mazafati and Zahedi varieties. After one year of storage, the Mazafati and Piarom varieties have the most $\mathrm{pH}$ value, and the Zahedi variety has the least one. After two years of storage, the Piarom variety with 6.31 and the Zahedi with 5.78 also have the most and least $\mathrm{pH}$ value. In all the varieties, with an increase in the duration of storage, the $\mathrm{pH}$ value of the samples has significantly decreased. The interaction as well as the duration of the maintenance of the samples in the store is also significant so that in general, the Mazafati and Zahedi varieties respectively have the most and least $\mathrm{pH}$ value, and with the passage of time, the $\mathrm{pH}$ value of the samples will be reduced. 
"Table 6" shows that both factors of variety and duration of maintenance in the store have had a significant effect on the acidity value of samples of dates. Among all the fresh samples, and the ones that after one and two years have taken into acidity measurement, the most value belongs to the Zahedi variety. The least acidity among the fresh samples belongs to the Mazafati variety and in the store samples, to the Piarom variety. The interaction of type of variety as well as the duration of maintenance of the samples in the store is also significant on acidity, and in general, with an increase in the duration of maintenance of the samples, their acidity value increases. In addition, generally, the Zahedi variety has allocated the most acidity and the Piarom as well as Mazafati varieties the least one to themselves.

Table 5: the effect of variety and storage time of varieties on $\mathrm{PH}$ value

\begin{tabular}{ccccc}
\hline Variety & \multicolumn{4}{c}{ Storage time (year) } \\
\cline { 2 - 5 } & 0 & 1 & 2 & Mean \\
\hline Piarom & $6.50 \pm 0.04^{\mathrm{c} \mathrm{A}}$ & $6.41 \pm 0.04^{\mathrm{a} \mathrm{B}}$ & $6.31 \pm 0.05^{\mathrm{aC}}$ & $6.41 \pm 0.09^{\mathrm{b}}$ \\
Zahedi & $6.03 \pm 0.03^{\mathrm{d} \mathrm{A}}$ & $5.91 \pm 0.02^{\mathrm{c} \mathrm{B}}$ & $5.78 \pm 0.02^{\mathrm{c} \mathrm{C}}$ & $5.91 \pm 0.11^{\mathrm{d}}$ \\
Kaluteh & $6.58 \pm 0.01^{\mathrm{b} \mathrm{A}}$ & $6.18 \pm 0.05^{\mathrm{b} \mathrm{B}}$ & $6.00 \pm 0.03^{\mathrm{bC}}$ & $6.25 \pm 0.26^{\mathrm{c}}$ \\
Mazafati & $6.97 \pm 0.02^{\mathrm{a} \mathrm{A}}$ & $6.39 \pm 0.05^{\mathrm{a} \mathrm{B}}$ & $6.10 \pm 0.17^{\mathrm{bC}}$ & $6.49 \pm 0.39^{\mathrm{a}}$ \\
Mean & $6.52 \pm 0.35^{\mathrm{A}}$ & $6.22 \pm 0.21^{\mathrm{B}}$ & $6.05 \pm 0.21^{\mathrm{C}}$ &
\end{tabular}

Averages with the same small letters in each column and averages with the same capital letters in each row do not have a significant difference with each other at the level of $\mathrm{P}<0.05$.

Table 6: the effect of variety and storage time of varieties on acidity

\begin{tabular}{|c|c|c|c|c|}
\hline \multirow{2}{*}{ Variety } & \multicolumn{4}{|c|}{ Storage time (year) } \\
\hline & 0 & $\overline{1}$ & 2 & Mean \\
\hline Piarom & $0.135 \pm 0.005^{\mathrm{bC}}$ & $0.163 \pm 0.004^{\mathrm{dB}}$ & $0.214 \pm 0.004^{\mathrm{dA}}$ & $0.171 \pm 0.035^{\mathrm{c}}$ \\
\hline Zahedi & $0.255 \pm 0.007^{\mathrm{a} \mathrm{B}}$ & $0.282 \pm 0.006^{\mathrm{aA}}$ & $0.297 \pm 0.017^{\mathrm{a} \mathrm{A}}$ & $0.278 \pm 0.021^{\mathrm{a}}$ \\
\hline Kaluteh & $0.121 \pm 0.006^{\mathrm{c} \mathrm{C}}$ & $0.234 \pm 0.008^{\mathrm{b} \mathrm{B}}$ & $0.263 \pm 0.004 \mathrm{~b} \mathrm{~A}$ & $0.206 \pm 0.065^{b}$ \\
\hline Mazafati & $0.094 \pm 0.006^{\mathrm{dC}}$ & $0.188 \pm 0.005^{\mathrm{c} \mathrm{B}}$ & $0.241 \pm 0.011^{\mathrm{c} \mathrm{A}}$ & $0.174 \pm 0.065^{\mathrm{c}}$ \\
\hline Mean & $0.151 \pm 0.065^{\mathrm{C}}$ & $0.217 \pm 0.048^{\text {В }}$ & $0.254 \pm 0.033^{\mathrm{A}}$ & \\
\hline
\end{tabular}

Averages with the same small letters in each column and averages with the same capital letters in each row do not have a significant difference with each other at the level of $\mathrm{P}<0.05$. Both factors of variety and duration of maintenance in the store have been effective in the amount of reducing sugars of glucose and fructose (invert sugars) of samples of dates "Table 7". The most amount of reducing sugar among the fresh samples belongs to the Mazafati and Kaluteh varieties. After two years of maintenance in the store, the Mazafati variety with $55.65 \%$ has the most value of reducing sugars. During the whole period of maintenance, the least amount of sugar belongs to the Zahedi variety. The interaction of type of variety as well as the duration of maintenance of the samples in the store is also significant on the value of reducing sugars, and in general, with an increase in the duration of maintenance of the samples in the store, their reducing sugar value decreases. In addition, generally, the Mazafati variety has allocated the most value of reducing sugars and the Zahedi variety the least one to themselves.

Table 7: the effect of variety and storage time of varieties on the value of reducing sugars Variety Storage time (year)

\begin{tabular}{lllll}
\hline \multirow{2}{*}{ Variety } & \multicolumn{4}{c}{ Storage time (year) } \\
\cline { 2 - 5 } & 0 & 1 & 2 & Mean \\
\hline
\end{tabular}




\begin{tabular}{|c|c|c|c|c|}
\hline Piarom & $54.87 \pm 2.44^{\mathrm{b} \mathrm{A}}$ & $48.81 \pm 1.42^{\mathrm{b} \mathrm{B}}$ & $44.21 \pm 1.76^{\mathrm{c} \mathrm{C}}$ & $49.30 \pm 4.92^{c}$ \\
\hline Zahedi & $50.31 \pm 1.72^{\mathrm{cA}}$ & $41.39 \pm 4.43^{\mathrm{c} \mathrm{B}}$ & $36.10 \pm 1.06^{\mathrm{d} B}$ & $42.60 \pm 6.68^{d}$ \\
\hline Kaluteh & $61.74 \pm 2.12^{\mathrm{aA}}$ & $56.03 \pm 0.65$ а в & $49.23 \pm 0.16^{\mathrm{bC}}$ & $55.67 \pm 5.54^{b}$ \\
\hline Mazafati & $61.78 \pm 2.26^{\mathrm{aA}}$ & $59.97 \pm 1.11 \mathrm{a} \mathrm{A}$ & $55.65 \pm 2.33^{\text {а в }}$ & $59.13 \pm 3.23^{a}$ \\
\hline Mean & $57.18 \pm 5.40^{\mathrm{A}}$ & $51.55 \pm 7.70^{\mathrm{B}}$ & $46.30 \pm 7.58^{\mathrm{C}}$ & \\
\hline
\end{tabular}

Averages with the same small letters in each column and averages with the same capital letters in each row do not have a significant difference with each other at the level of $\mathrm{P}<0.05$.

\section{Conclusion:}

Review of the collected data from this study shows well the significant effect of the variety and the duration of maintenance of samples in the store on the various features of dates. In terms of the amount of moisture, Kharak Berhi with $72.07 \%$ has dramatically had more moisture than the other samples. The reason for this issue is that the Berhi sample used in this research is at the stage of Kharak in which the amount of water of samples is more than ripe dates and the amount of their sugar is less [8].

The most value of length and width with 41.07 and $24.95 \mathrm{~mm}$ respectively belongs to the Piarom and Mazafati varieties that these values are more concerned with issues reported by other researchers about other types of dates. In this study, the most thickness with $20.70 \mathrm{~mm}$ belonged to the Kharak Berhi variety that this one is less than the thickness reported by other researchers for the Mazafati and Lasht varieties. The largest surface area belonged to the Mazafati variety that this number is equal to the one reported for the Lasht variety and more than the one reported for Dairi variety. In this research, the most sphericity coefficient with $82.8 \%$ was obtained for Kharak Berhi and the least sphericity coefficient with $55 \%$ for Piarom dates. These coefficients are respectively more or less than the values reported by other researchers for the Mazafati, Lasht, and Dairi varieties [26-28, 38-39].

The most volume of fruit with $10.79 \mathrm{~cm}^{3}$ was allocated to the Mazafati variety that is more than similar varieties for other varieties. The least volume of fruit with $6.45 \mathrm{~cm}^{3}$ also belonged to the Berhi variety that is more than the value reported for the Dairi variety and less than the volume of fruit of the Lasht variety [26-28]. The most mass density with $601 \mathrm{~kg} / \mathrm{m}^{3}$ was concerned to the Mazafati variety that is more than similar values for the Lasht, Dairi, Khasooei and Shahani varieties and less than the mass density of Haj Ghanbari variety. The least mass density also with $472 \mathrm{~kg} / \mathrm{m} 3$ belonged to the Kaluteh variety that is less than other ones. The Kaluteh variety with $58 \%$ had the most porosity among other samples that its number is also more than the obtained value for other types of dates. Kharak Berhi with $46.6 \%$ also had the least value of porosity that this variety is less than porosity of the Dairi, Shahani, and Haj Ghanbari varieties; more than porosity of the Khasooei variety and equal to porosity percentage of the Lasht variety [27-28, 38-39] Meanwhile, the results of this research represent a significant effect of the type of varieties of dates and also material of surfaces on static coefficient of friction. In addition, the results of this study indicated that type of variety of dates and its duration of maintenance have a significant effect on $\mathrm{pH}$, acidity and percentage of existing reducing sugars in dates. In general, with an increase of the maintenance time, the amount of reducing sugars is reduced and acidity can be added; as a result, the $\mathrm{pH}$ value is also reduced. In this review, the amount of reducing sugar in the fresh varieties of Mazafati, Kaluteh, Piarom, and Zahedi was obtained respectively equal to $61.78,61.74,54.87$, and $50.31 \%$. The amount of reducing sugar mentioned in various sources depending on the type of variety of dates and method of measurement is very different and variable from $53 \%$ to $75 \%$. The amount of reducing sugar of the Mazafati variety has been reported by other researchers from 60.7 to $75 \%$ [40-41].

\section{References:}

[1] Dictionary of Food Science and Technology, 2005, International Food Information Service (IFIS Publishing) Blackwell Publishing, p.108. 
[2] Ahmed, J. and H.S. Ramaswamy, 2006, Physico-chemical properties of commercial date pastes (Phoenix dactylifera), Journal of Food Engineering, 76, 348-352.

[3] Al-Hooti, S.N., J.S. Sidhu, J.M. Al-Saqer and A. Al-Othman, 2002, Chemical composition and quality of date syrup as affected by pectinase/cellulase enzyme treatment, Food Chemistry, 79, 215-220.

[4] FAO, 2004, Date palm production chapter 1 and 2, downloaded from FAO Website: www.FAO.org on 2007/05/24.

[5] FAO, 2005, Statistical Databases, Available at http://faostat.fao.org; consulted 9 January 2009.

[6] Mireei, S.A., Mohtasebi, S.S., Massudi, R., Rafiee, Sh., Arabanian, A.S., and Berardinelli, A., 2010, Nondestructive measurement of moisture and soluble solids content of Mazafati date fruit by NIR spectroscopy, Australian journal of crop science 4(3), 175-179.

[7] FAOSTAT, 2006, Statistical Year Book of FAO, Available in: http:// faostat.fao.org.

[8] Al-Shahib, W., Marshall, R.J., 2003, The fruit of the date palm: its possible use as the best food for the future, International Journal of Food Sciences and Nutrition, 54 (4), 247-259.

[9] Amoros, A., Pretel, M.T., Almansa, M.S., Botella, M.A., Zapata, P.J., and Serrano, M.,2009, Antioxidant and Nutritional Properties of Date Fruit from Elche Grove as Affected by Maturation and Phenotypic Variability of Date Palm, Food Science and Technology International, 15(1), 65-72.

[10] Bahramian, S., Azin, M., Chamani, M., and Gerami, A., 2011, Optimization of Enzymatic Extraction of Sugars from Kabkab Date Fruit, Middle-East Journal of Scientific Research, 7(2), 211-216.

[11] Silva, E.M., Souza, J.N.S., Rogez, H., Rees, J.F., and Larondelle, Y., 2007, Antioxidant activities and polyphenolic contents of fifteen selected plant species from the Amazonian region, Food Chemistry, 101, 10121018.

[12] Javanmardi, J., Stushnoff, C., Locke, E., and Vivanco, J.M., 2003, Antioxidant activity and total phenolic content of Iranian Ocimum accessions, Food Chemistry, 83, 547-550.

[13] Vayalil P.K., 2002, Antioxidant and antimutagenic properties of aqueous extract of date fruit (Phoenix dactylifera L. Arecaceae), Journal of Agricultural and Food Chemistry, 50, 610-617.

[14] Siahpoush, A., Gole fakhrabadi, Fereshte., and Jorkesh, Fatemeh., 2011, Determining and comparison of the antioxidant capacity in water and methanol extract of date fruit, dayri variety of Abadan, Journal of research in medicine [in Persian], 35(2), 81-86.

[15] Biglari, F., Abbas F.M. AlKarkhi, Mat Easa, A., 2008, Antioxidant activity and phenolic content of various date palm (Phoenix dactylifera) fruits from Iran, Food Chemistry, 107, 1636-1641.

[16] Kaur C. and Kapoor H.C., 2001, Antioxidants in fruit and vegetables- The millennium' health, International Journal of Food Science and Technology, 36, 703-725.

[17] Ferrari, C.K.B., and Torres, E.A.F.S., 2003, Biochemical pharmacology of functional foods and prevention of chronic diseased of aging, Biomedicine and Pharmacotherapy, 57, 251-260.

[18] Miller, C.J., Dunn, E.V., and Hashim, I.B., 2003, The glycaemic index of dates/yoghurt mixed meals. Are dates 'the candy that grows on tress'?, European Journal of Clinical Nutrition, 57, 247-430.

[19] Zangiabadi, N., Asadi-Shekaari, M., Sheibani, V., Jafari, M., Shabani, M., Asadi, A.R., Tajadini, H., and Jarahi, M., 2011, Date Fruit Extract Is a Neuroprotective Agent in Diabetic Peripheral Neuropathy in StreptozotocinInduced Diabetic Rats: A Multimodal Analysis, Hindawi Publishing Corporation Oxidative Medicine and Cellular Longevity, Article ID 976948, 9 pages.

[20] Forghani, B., Kasaeeyan, N., Tala Minayi, M., Zare, M., Haghighi, S., and Amini, M., 2003, Effect of date fruit on the blood sugar in type II diabetic women in the gland and metabolism research center of Isfahan province, Journal of Shahid Sadughi medical sciences university of Yazd [in Persian], 10(4), 52-55.

[21] Razaghi Azar, M., Nouri, N., and Afsharian, K., 2005, The effect of date fruit on the blood sugar in diabetic type I patients, Journal of diabet and lipid of Iran [in Persian], 4(3), 27-34.

[22] Sayyedi, A., Asgarian, SH., Khalifeh Borazjani, H., and Kohanteb, J., 2007, Effect of Date Extract on Growth of Mutans Streptococci, the Most Important Factor of Dental Caries, Journal of Armaghane Danesh [in Persian], $11(4), 63-71$.

[23] Hojjati, M., 2008, Oil Characteristics and Fatty Acid Aontent of Seeds from three Date Palm (Phoenix Dactylifera L.) Cultivars in Khuzestan, Journal of Food Science and Technology [in Persian], 5(1), 69-74.

[24] Ataye Salehi, E., Hadad Khodaparast, M.H., Lame, S.H., Habibi Najafi, M.B., and Fatemi, S.H., 2010, Determination of chemical composition and fatty acids profile of date seed, Journal of Food Science and Technology [in Persian], 7(2), 85-90.

[25] Shariati, A., Pordeli, H.R., Khademiyan,A., and Kyaie, E., 2010, Evaluation of the Antibacterial Activity of the Extracts of Date Palm (Phoenix dactylifera L.) Fruits and Pits on Multi-Resistant Staphylococcus aureus. Food Technology and Nutrition [in Persian], 7(4), 42-48. 
[26] Jahromi, M.K., Mohtasebi, S.S., Jafari, A., Mirasheh, R., and Rafiee, S., 2008, Determination of some physical properties of date fruit (cv. Mazafati), Journal of Agricultural Technology, 4(2), 1-9.

[27] Keramat Jahromi, M., Jafari, A., Rafiee, S., Keyhani, A. R., Mirasheh, R., and Mohtasebi, S.S., 2007, Some Physical properties of Date Fruit (cv. Lasht), Agricultural Engineering International: the CIGR Ejournal. Manuscript FP 07 019. Vol. IX. August, 1-7.

[28] Keramat Jahromi, M., Rafiee, S., Jafari, A., Ghasemi Bousejin, M.R., Mirasheh, R., and Mohtaseb, S.S., 2008, Some physical properties of date fruit (cv. Dairi), International Agrophysics, 22, 221-224.

[29] Markhand, G.S., Abul-Soad, A.A., Mirbahar, A.A., and Kanhar, N.A., 2010, Fruit Characterization of Pakistani Dates, Pakistan Journal Of Botany, 42(6), 3715-3722.

[30] A.O.A.C., 2002, Official Methods of Analysis, 17th Ed. Association of Official Analytical Chemist, Aithersburg, M.D.

[31] McCabe, W.L., Smith, J.C., and Harriott, P., 1986, Unit operations of chemical engineering, McGraw-Hill Publisher, New York.

[32] Kabas, O., Ozmerzi, A., and Akinci, I., 2006, Physical properties of cactus pear (Opuntia ficus India L.) grown wild in Turkey, Journal of Food Engineering, 73, 198-202.

[33] Mohsenin, N.N., 1978, Physical properties of plant and animal materials. New York: Gordon and Breach.

[34] Razavi, M.A., and Akbari, R., Biophysical properties of agricultural and food materials, 2012, Ferdowsi university of Mashhad press [in Persian], 3rd edition.

[35] Technical Services Department Hunter Associated Laboratory, Inc. 1996, Application Note, 8, 1-15.

[36] Afshari Jouybari, H., and Farahnaky, A., 2011, The effects of acetic acid and sodium chloride solutions on accelerated ripening of Mazafati date, journal of food industries researches [in Persian], 21(2), 219-227.

[37] A.O.A.C., 1984, Official Methods Of Analysis, $14^{\text {th }}$ Edition, Association of Official Analytical Chemists, Washington D.C.

[38] Keramat Jahromi, M., Rafiee, Sh., Jafari, A., Mohtasebi, S.S., and Mirashe, R., 2008, Comparison of some physical properties of date fruits (Haj Ghanbari and Shahani varieties), Journal of biosystem engineering of Iran [in Persian], 39(1), 85-92.

[39] Keramat Jahromi, M., Jafari, A., Rafiee, Sh., Mirashe, R., and Mohtasebi, S.S., 2008, Determining and comparison of some physical characteristics of date fruits (Berhi and Khasoei varieties), Journal of agricultural sciences and natural resources [in Persian], 15(1), 1-9.

[40] Keramat, J., and Khorvash, M., 2002, Composition of main Iranian varieties of dates, Journal of agricultural and natural resources sciences [in Persian], 6(1), 189-197.

[41] Maghsoudlou, Y., Motamedzadegan, A., Esmaeelzadeh Kenari, R., and Hamzehe, S., 2005, Evaluation of chemical composition and energy content of three common varieties of Iranian dates, Journal of agricultural sciences and natural resources [in Persian], 12(1), 47-51. 